ANGELA BOGGERO (*)

\title{
MACROINVERTEBRATES OF ITALIAN MOUNTAIN LAKES: A REVIEW
}

\author{
(*) LifeWatch Italy, http://www.servicecentrelifewatch.eu and CNR - Institute of Ecosystem Study (ISE), Largo V. Tonolli \\ 50, 28922 Verbania Pallanza, Italy \\ $\left(^{*}\right)$ Corresponding author email: a.boggero@ise.cnr.it
}

\section{Boggero A. - Macroinvertebrates of Italian mountain lakes: a review}

The paper summarizes the state of knowledge and the evolution of the researches on benthic macroinvertebrates of Italian mountain lakes, and identifies key aspects that need to be further explored. Mountain lakes have been investigated since the end of the XIX century. In the beginning, studies focused mainly on their geography, geology, geomorphology and hydrology. Only lately, interests arise on their hydro-chemistry and biology, in relation to water acidification and, in rare cases, to eutrophication. In particular, in the 1920 s, the studies dealt mainly on lake basins morphology and their genesis. Later, researches were driven mainly by the growing need of hydroelectric power plants, shifting the attention on their hydrological and geological aspects. Nonetheless, more detailed limno-biological studies began in confined areas. During the 1960s, attention was redirected to the alpine environment in terms of environmental awareness, for the creation of parks, and to analyse the alteration of water quality caused by the deposition of transported pollutants from the lowlands. This created the opportunity to combine observations on both the hydro-chemical and biological aspects, to reach a synoptic view of these environments. It is only in the mid-1990s that ISI journals came to power and, striving for higher visibility, strongly promoted the production of papers. In this decade, the application of paleo-limnology, the creation of a long term ecological research network, the never abandoned idea of implementing best practice management for freshwaters conservation purposes, and the growing attention on the global climatic change gave new impulse to the studies on mountain lakes. Since the 2000s, biodiversity preservation, biological recovery, environmental key-drivers (mainly nitrogen increase) have become the new focus of the current research activities.

KeY WoRDS: Alps, Apennines, limnology, geographic distribution, historical perspective

\section{To my father and to his passion for mountains}

\section{PREMISE}

In Italy there are thousands of lakes, considering natural and artificial systems, placed at different altitudes: in particular, there are about 1100 natural lakes with an area greater than $0.01 \mathrm{~km}^{2}$ and more than 4000 lakes, listed in the Alps, and characterized by small surfaces and high environmental value (NARDINI \& SANSONI, 2006; TARTARI et al., 2006). However, a comprehensive catalogue for these mountain lakes is still missing, because, at present, no universally accepted definition allows the clear separation among lakes, ponds, pools and wetlands (WHITAKER \& AMLANER, 2012).

Mountain lakes are traditionally defined as lentic ecosystems located above the tree line (CATALAN et al., 2009). This is the limit that separates the subalpine and the alpine areas, but its position depends on different climatic conditions that affect the growth of trees (KöRNER, 1998). Currently, at a European level, the Water Framework Directive (EU, 2000) do not take into account this natural border, and strictly define mountain lakes as those systems located above $2000 \mathrm{~m}$ asl. Since conspicuous variations within the same mountain chain can affect the location of the tree line (besides altitudes, latitude, slope and other factors) (GRACE et al., 2002), in this review I do not strictly respect these definitions, and I considered all the lakes above and close to the tree line.

Mountain lakes, characterized by harsh climatic and edaphic conditions, are frequently lacking of tributaries and are mainly fed by melting snowfields and glaciers. Although most of the mountain lakes originated during the last glacial retreat (approximatively 10,000 years ago), new ones are still forming due to global warming (SALERNO et al., 2014). The main environmental characteristics of these systems are, in general, low depths (maximum depths, at mean water level, $>1 \mathrm{~m}$ ), small dimensions (surface areas $>0.01 \mathrm{~km}^{2}$ ), cold water temperatures $\left(<20^{\circ} \mathrm{C}\right.$ even in summer), long ice cover periods (up to 8 months), low buffering capacity (mainly in correspondence of acidic geo-lithology) and nutrient levels, extreme changes in light penetration between ice-covered and ice-free lake surface (SOMMARUGA, 2001). Moreover, frequent water mixing can occur because of their peculiar morphological features and wind exposure.

Because of these severe environmental conditions, these ecosystems host relatively simplified biological communities, almost homogeneous along the water column, but increasing in complexity and diversity along the littorals. Large animals are represented by few amphibians and fish, but, in most cases, vertebrates are totally and naturally lacking. The biological component is typically represented by phytoplankton and zooplankton (TOLOTTI et al., 2006), macrophytes (occasionally, CHAMBERs et al., 2008) and macroinvertebrates. The latter group include immature and adult stages of many different types of invertebrates that colonize all types of water bodies. Their distribution is mainly influenced by substrate, water depth, temperature, chemistry, food availability, and they act as a crucial link in the food webs by connecting organic matter resources with lower and higher trophic levels (HAUER \& RESH, 2006).

Even if a direct anthropic pressure on mountain lakes is 
scarce (they are usually distant from urban areas and difficult to access), these systems can receive pollutants from regional and long-range atmospheric transport (KALLENBORN, 2006). Moreover, the reduced water renewal capacity and the presence of simplified food webs make these lakes extremely sensitive to environmental changes (PSENNER, 2002). For this reason, they are important sentinels of global climate changes (PARKer et al., 2008; FenOGLIO et al., 2010), and are among the most threatened surface systems in Italy. Currently, they are also among the less investigated ones. Notwithstanding their crucial importance, because of their small dimensions they are not included under the monitoring programs of the Water Framework Directive legislation.

From the beginning of 1900 , macroinvertebrates were used in the biomonitoring programmes of many European lowland lakes that were showing serious symptoms of eutrophication (NAUmann, 1921; LenZ, 1925; LundBeck, 1936; ThIENEMANN, 1954; BRUNDin, 1956). It was only some decades later that their employment in the ecological classification of lakes became popular (WIEDERHOLM, 1981; KANSANEn et al., 1984; AAGAARD, 1986; RossARO et al., 2010). Macroinvertebrates constitute one of the elements for the ecological evaluation of lakes. They are considered good indicators of freshwaters quality (ALLAN \& CASTILLO, 2007), as their assemblage changes in relation with trophic condition, oxygen saturation, temperature and depth.

Macroinvertebrates sampling of mountain lakes constitutes a tricky debate among scientists. Mountain invertebrate sampling methods must comply with standards tailored to highlight the peculiar environmental conditions, through the analysis of their heterogeneous fauna found along the shores where sampling is easier (NIVA, 1987, 1995, 2010). Indeed, protection and management plans, and conservation efforts of mountain lakes cannot overlook a thorough understanding of the biological diversity of these environments, which still appears fragmented and limited to some biotic components or sectors of the Alps.

In this paper, a summary of the available knowledge on benthic macroinvertebrates of Italian mountain lakes, and of topics for future research is presented. In particular, this article reviews studies on benthic macroinvertebrates that were mainly carried out in mountain lakes at both the southern side of the Alps and at the higher altitudes of the
Apennines. Mountain lakes from these two mountainous ranges, despite possible biogeographical differences, are considered together because they play a major role as essential environmental end ecological elements, they are important sources of water and touristic attraction, and they share similar threats at local and global scale.

\section{SEEKING FOR BIBLIOGRAPHIC SOURCES}

During the early preparation of this article, various Italian and foreign limnologists share their historical bibliography and advised on their field of expertise. A first search for old papers was carried out in the dusty catalogues, archives and on the online library of the CNR-Institute of Ecosystem Study, which hosts one of the largest and most comprehensive European collection of papers on limnology and hydrology. Papers that were not locally available were searched at academic or museum libraries. As for recent authors, Internet (mainly Google Scholar) provided bibliographic information, titles, authors and sources, speeding up time, and saving energy.

A total of 96 published papers were obtained for the period 1900-2017, including grey literature, educational, national and international scientific articles. The distribution of the different taxonomic groups among bibliographic resources is depicted in Fig. I. On the basis of the collected papers, the Table 1 (see Supplementary material 1) was prepared reporting information on latitude and longitude (WGS 84 data), altitude, maximum depth, and type of data found in each paper (presence/absence of species, families, or macroinvertebrates groups, relative abundances, absolute abundances, densities). Data are referred to different mountain ranges, different administrative regions, and different lakes. The geographic information reported in each paper was checked and corrected using either Google maps, the lake cadastre of the regions or provinces, or specific weblinks (for more detailed information see BOGGERO et al., 2017). In the cases of changes in the name of a lake during its history or when the same lake has two different names, both names has been kept to avoid the loss of information. The list of species found in each lake and their updated taxonomy, divided per mountain range, per different administrative regions, per lake and per year of citation, is reported in BOGGERO et al. (2017) and, as a data set, is available at the CNR-ISE website (http://www.ise.cnr.it/it/products/datasets).

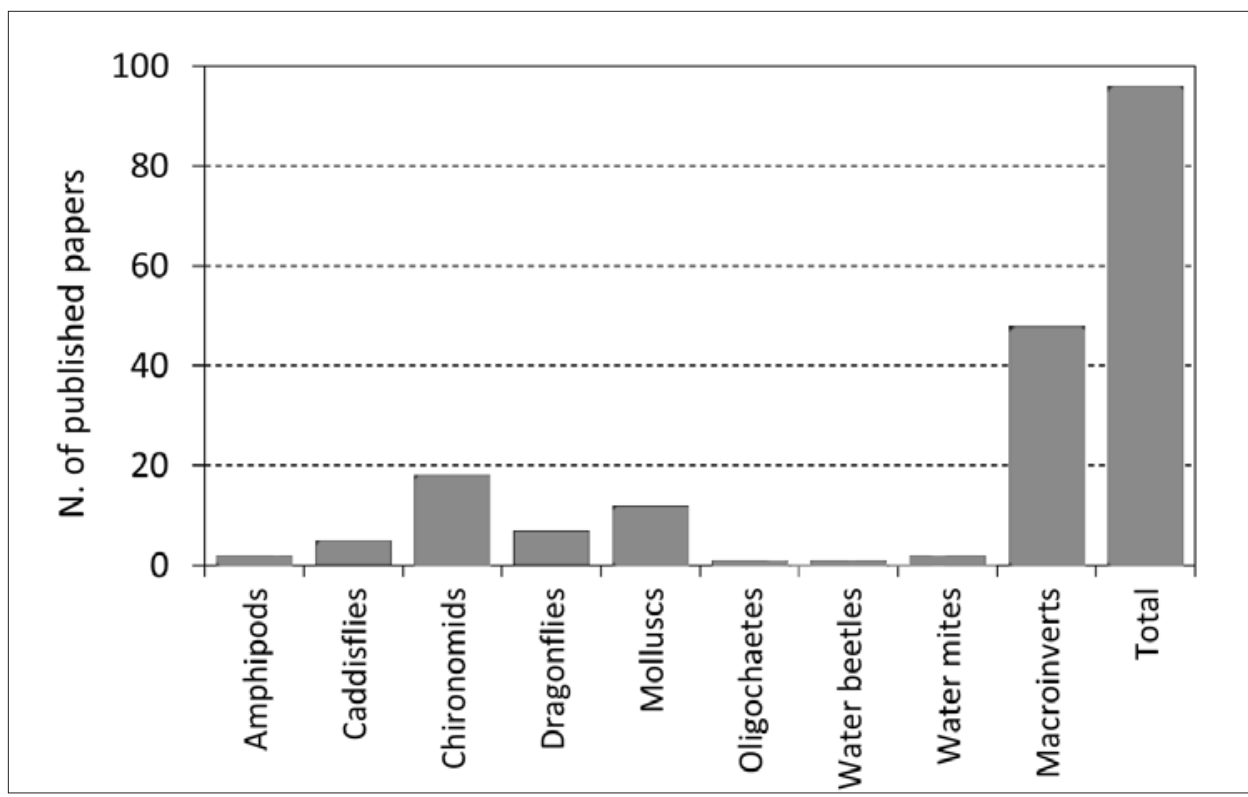

Fig. I - Papers published in the period 1900-2017 on the lacustrine macroinvertebrates in Italian mountain areas, divided per each taxonomic group. 
THE EUROPEAN SCENARIO AT THE TURN OF THE XX CENTURY Since the end of XIX century, aquatic environments of mountainous areas have received growing attention, because of their uniqueness, importance for water supplies, and vulnerability. In this period, pioneering studies started in European countries where mountains cover vast areas of the territory. This is the case of Italy (PERO, 1893; DE MARCHI, 1913a, b), Switzerland (ZschOKKe, 1894; BOURCART, 1906), and Austria (PESTA, 1912). These early researches considered mountain lakes as small and simplified systems to test and verify new hypothesis and theories. Furthermore, these lakes, characterised by a relatively simple fauna, were also captivating because of the high probability to find new species, frequently endemic. Thanks to these studies, a growing corpus of information on these water bodies, their origin and morphology, their chemical-physical structure, and their biological composition (mainly plankton and phyto-benthos) was acquired. Nonetheless, these early biological studies had a more taxonomical than a biogeographical or ecological perspective.

SEARCHING FOR ITALIAN MEMORIES (1900-1940)

In Italy, the first mentions of lacustrine benthos dates back to the beginning of the XX century: before World War I, the University of Padova carried out some sampling campaigns in Trentino aimed at characterizing the limnology of mountain lakes (BUFFA, 1902; LARGAIOLLI, 1907). In these early studies, researchers accidentally caught benthic macroinvertebrates through plankton hauls. After these early reports, no further study was carried out over a rather long period. This is mostly because of the logistic difficulties to sample high altitude freshwaters characterized by short ice-free periods in largely unexplored areas. In the 1930s, the Museum of Natural History of Milan launched a research project in the Gran Paradiso National Park to study the presence and the distribution of molluscs, including lentic species (GAMBETTA, 1932). Another pioneering work was performed by the University of Milan on the biological communities of Lake Valparola. Because of the peculiar geological composition of its catchment, this dolomitic lake drew the attention of Rina Monti, one of the most prominent Italian limnologist, which was surprised and satisfied by the discovery of an unusual community characterized by numerous Gammaridae typically associated with lower altitudes and running waters (MonTI, 1936).

\section{The ITALIAN MidDLE AGE (1940-1990)}

In the 1940s, Lake Tovel became one of the most studied Alpine lakes because the reddening of its waters attracted many researchers, including some benthologists (BALDI, 1941; MORETTI, 1942). Subsequently, researchers started to broaden their attention from single lakes to lakes grouped on entire mountain valleys (TONOLLI, 1949), mountain ranges (the Dolomites: MARCUZZI, 1956, 1961 or the entire Alps: MARCUZZI, 1988), provinces (BARBATO, 1984; BLESIO, 1985) or national parks (TORTONESE \& ROSSI, 1954; PARISI et al., 1968; GiANOTTI \& Di GiovanNi, 1971). They highlighted major species pattern of distribution, and the relation between community and lake morphological and chemical properties, focusing on the bio-limnological aspects in natural lakes (MARCHESONI \& MORETTI, 1954) and reservoirs (SOMMANI, 1952; BazZANTI \& SeminaRa, 1987; MastrantuONO, 1987; BAZZANTI et al., 1988). Some authors focused on boreoalpine species (RUFFO, 1951) or on specific groups (e.g., TERZANI, 1977, and MASCAGNI \& TERZANI, 1983 on dragonflies). Nonetheless, ecological studies were also realised, concerning, for example, the impact of fish predation on benthos occurrence and biomass (FERRARI \& BELLAVERE, 1976). Afterwards, growing interests were directed towards the relationship between the macroinvertebrate assemblages and the environmental quality, in particular regarding trophic status (Boni et al., 1983; BAzZANTI et al., 1988; CASEllato \& ZANFEI, 1988; SEMINARA \& BAZZANTI, 1988) and acidification (GARIBALDI et al., 1987) of lakes. These studies were supported by the growing scientific, but also touristic and economic, importance of mountain lakes. In this context, macroinvertebrates became one of the crucial elements for evaluating the lacustrine environmental conditions and, at the end of the 1990s, macroinvertebrates, never considered before in national and European regulations, were finally incorporated in the Water Framework Directive (2000/60/EC - EU, 2000).

\section{ITALIAN MODERN TIMES (1990-TO PRESENT)}

The beginning of the 1990 s was characterized by an increasing attention towards the ecology and distribution of trichopterans (CIANFICCONI \& MORETTI, 1992) and a renewal of the studies on Lake Tovel (MoretTI \& CorALLinI SorCETTI, 1991; PAgANELli, 1992). At the same time, a significant revolution took place: due to the launch of broad-scale European projects on freshwater acidification impacts (ALPE, MOLAR, EMERGE), the number of papers regarding Italian mountain lakes grew conspicuously (Fig. II). Thanks to these projects and to the acknowledgement of the idea of an Italian network for long-term ecological research, a few high altitude lakes (upper and lower lakes Paione, Anterselva, Braies, Monticola, Tovel and lakes Santo and Scuro Parmense), representing the Alps and the Apennines, were chosen as part of the "Mountain Lakes" LTER macrosite (LTER Italy http://www.Iteritalia.it/). Lakes Paione underwent multidisciplinary studies also considering macroinvertebrates (Mosello et al., 1993; Boggero \& Nocentini, 1994; BogGERo et al., 1996; GuILIZZONI et al., 1996).

In the second half of the nineties, to improve the correct management of freshwater habitats and to analyse water acidification processes, other high altitude lakes were considered, like those on the Gran Sasso (Central Italy - Di Giorgio \& ZupPA, 1996), those lying in the Monte Avic Natural Park (Aosta Valley - Novelli et al., 1997; FACCHINI \& BADINO, 1998), and those in the Lake Maggiore watershed (Ossola Valley - Boggero, 1995; Boggero \& Nobili, 1998). In the year 2000, a study on Chironomidae of Italian lakes allowed, for the first time, to distinguish between oligotrophic mountain and eutrophic lowland lakes on the basis of the presence/absence of peculiar species (MIETTO et al., 2000), and to propose indicator values for different midge taxa. In the same period, important findings on remote lakes were published at a Pan-European (FJELLHEIM et al., 2000) and Alpine level (BOGGERO et al., 2006; FürEDER et al., 2006), demonstrating the value of mountain lakes as indicators of local and global temperature changes. Then, a series of studies were carried out, mainly inside national parks, attempted to reconcile the traditional exploitation of mountain lakes as drinking trough for cattle with the conservation needs of these fragile freshwater ecosystems (RUGGIERO et al., 2001, 2004; LENCIONI, 2001; BogGERO et al., 2005).

New works on the biogeographical distribution of molluscs were also carried out, highlighting threatened species and areas towards which conservation efforts were needed (DECET \& Fossa, 2001; EVANGElista, 2009; NARDI \& CASTAGNOLO, 2009; NARDI, 2014). Research efforts were again directed towards Lakes Paione, showing the first signs of a biological recovery after twenty years of limnological studies (MARCHETTO et al., 2004), and Lake Tovel, with a first study on the evolution of 


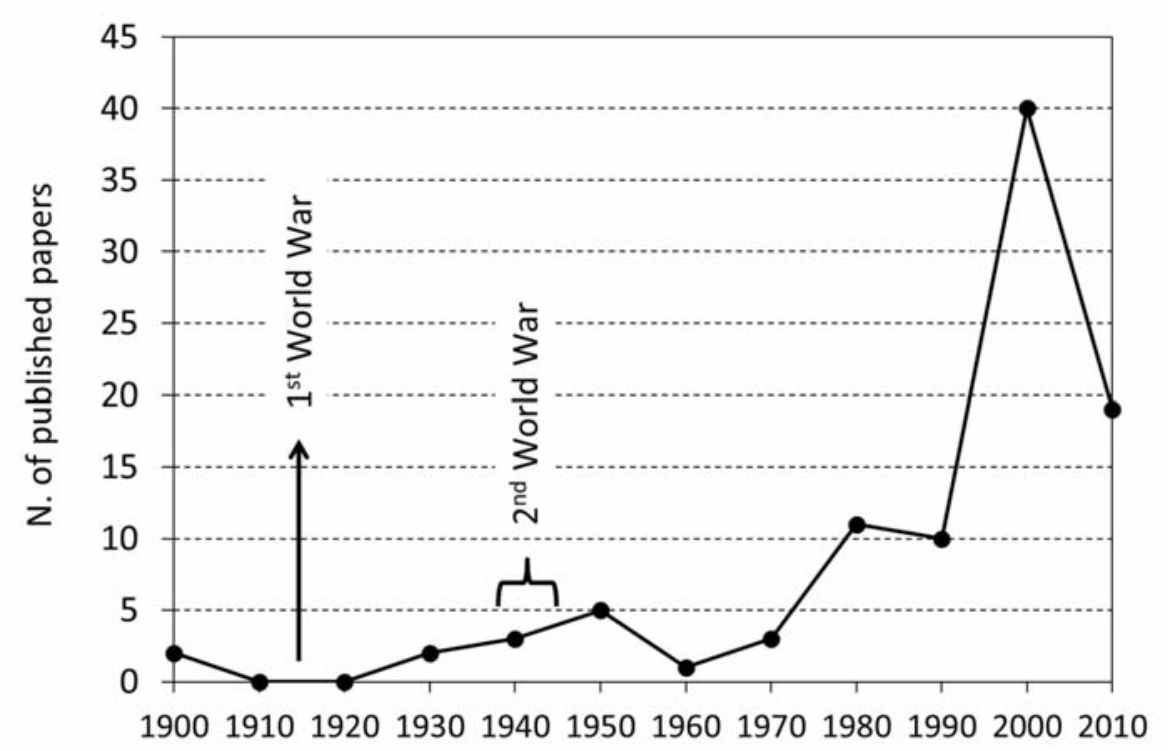

Fig. II - Decadal estimate of the number of published papers on macroinvertebrates of the Italian mountain lakes

the caddisfly fauna after the ending of the water reddening (CAPPELlETTI et al., 2004). Others studies were focused on Chironomidae or, more in general, on invertebrates through neo- and paleo-ecological approaches (FERRARESE, 2002; FRANCESCHINI \& LENCIONI, 2002; FERRARESE \& LENCIONI, 2003; LENCIONI \& LAZZARA, 2004; FILIPPI et al., 2005a, 2005b; HEIRI et al., 2005; MARZIALI et al., 2005; BOGGERO \& LENCIONI, 2006; LAZZARa et al., 2006; DeCET, 2007a, 2007b; Millet et al., 2007; MoRABITO et al., 2007-2008; CANTONATI et al., 2014). Researches focused on more specific topics, such as the distribution of Gammarus lacustris (IANNILLI et al., 2004), and the ecology of Hydrachnidia (DI SABATINO et al., 2004; MICCOLI et al., 2005), Oligochaeta (DUMNICKA \& BogGERO, 2007, 2017), or Odonata (DECET, 2007c; DAL CORTIVo et al., 2009) were carried out.

In 2009, two papers at a European level (CATALAN et al., 2009; FJELLHEIM et al., 2009) highlighted that four main lake features (size, tropho-dynamic status, acid-base balance and ice-cover duration) affect the macroinvertebrates assemblage in Alpine lakes. The same works pointed out, for the first time, that species inventory at high altitude was still incomplete due to critical problems in sampling designs. Meanwhile, other researches draw the attention on the growing impact of anthropogenic nitrogen inputs in the shaping of biological lake communities. So important that the biological lake communities could be used to estimate the water quality status not only in lowland (BOGGERo et al., 2009), but even in mountain lakes (MARCHETTO et al., 2009).

In the last decade, the SHARE Stelvio project (Stations at High Altitude for Research on the Environment) was launched. It was devoted to Alpine freshwaters as the last sources of uncontaminated waters, suitable to sustain biological communities poorly altered or unaltered by human impacts (LAMI et al., 2011; BOGGERO et al., 2012, 2018 submitted). In the very last years, interesting studies were also realized in the Gran Sasso and Gran Paradiso National Parks (Osella \& PANNUNZIO, 2013; KHAMIS et al., 2014), and in the Northern Apennines (ANSALONI et al., 2015, 2016), areas acknowledged for their high conservation value. Even if some recent papers investigated the taxonomy and autecology of mountain lake macroinvertebrates (e.g., ROSSARO et al., 2010, 2012), many aspects regarding the biology or the ecology of these organisms remain underestimated or even unknown in the entire mountain range (TIERNO DE FIGUEROA et al., 2012).

In the last twenty years, in support to the mass diffusion of knowledge, a number of educational papers, pocket books, booklets and e-books regarding the Italian Alpine mountain lakes and their ecological importance, often focusing on macroinvertebrates, have been produced (BIANCOTTI et al., 2001; Boggero \& MOVALLI, 2001; MARCHETTO et al., 2001; NARDI, 2005, 2010a, 2010b; NÖSSING \& WINKLER WerTH, 2010; BogGERO et al., 2013; RogorA et al., 2014).

\section{MACROINVERTEBRATES: HISTORICAL INFORMATION}

AND NEW RECORDS FROM ITALY

The first studies on mountain lakes provided very little information on their faunal assemblage, because researchers used to identify macroinvertebrates only as a group, or, seldom, to talk about few classes or families and to give only a general idea of their presence (BUFFA, 1902; LARGAIOLLI, 1907; Gambetta, 1932; Monti, 1936; Baldi, 1941; MoRETTI, 1942; RUFFO, 1951). Hydro-biological studies providing a differentiation between littoral and profundal faunal records date back to the 1950s (SOMMANI, 1952; MARCHESONI \& MoretTi, 1954; TORTONESE \& Rossi, 1954). However, list of species were only provided starting from the $1980 \mathrm{~s}$ (MAStrantuono, 1987; BazZanti et al., 1988; CASEllato \& ZANFEI, 1988).

\section{Central western Alps}

Oligotrophic or ultra-oligotrophic lakes of the Central western Alps, characterized by acidic rocks with low buffering capacity and low ionic concentrations, host a low diversity, with assemblages dominated by Insecta and Oligochaeta, and minor abundances of Platyhelmintes and Mollusca (Boggero \& Nocentini, 1994; Boggero, 1995; Boggero et al., 1996; BogGero \& NoBILI, 1998). In general, at higher altitudes where cold and extreme climate shape the environment, the taxonomic composition of Chironomidae (Diptera) is represented mainly by the subfamilies Orthocladiinae and Chironominae tribe Tanytarsini. On the contrary, lower altitude lakes are dominated by the subfamily Chironominae tribe Chironomini (BOGGERO et al., 2006). Along the littorals, it is easy to find also the subfamilies Tanypodinae and Prodiamesinae. Orthocladiinae are repre- 
sented by Heterotrissocladius, Psectrocladius and Corynoneura, Chironominae-Tanytarsini by Micropsectra and Paratanytarsus, Tanypodinae by Zavrelimyia, and Prodiamesinae by Prodiamesa olivacea (Meigen, 1818). Noticeable is the presence of rare species like Acamptocladius reissi Cranston and Saether 1982 (Orthocladiinae), recorded for the first time in Italy on the Central western Alps in 1993 and representing here an extension of its biogeographical distribution (BOGGERO, unpublished data). Another species, rare here and problematic to identify at the larval stage, is Protanypus sp.(Diamesinae) (RossARo et al., 2012).

Oligochaeta followed in importance, usually representing about $10-20 \%$ of the macroinvertebrates assemblage, but rarely determined to species level (DUMNICKA \& BOGGERO, 2007). Families that are frequently retrieved are Naididae [Nais communis Piguet, 1906 and N. bretscheri (Michaelsen, 1898)] and Enchytraeidae (Henlea perpusilla Friend, 1911, Mesenchytreus armatus (Levinsen, 1884), Cernosvitoviella atrata (Bretscher, 1903) and C. microtheca (Rota and Healy, 1999).

Then, Trichoptera Limnephilidae, Plecoptera Nemouridae, Coleoptera Dytiscidae, Hydrachnidia, and Mollusca Bivalvia Sphaeriidae (mainly Pisidium casertanum Poli, 1791) are taxa common at these altitudes (BOGGERo \& NocENTINI, 1994; BOGGERO et al., 1996; NARDI, 2005).

Hydrachnidia, as Chironomidae, are mainly characterized by stenothermic rheobionts and crenobiontic species, since slow-flow conditions are present along the littorals of these lakes (Di SABATINO et al., 2004, MicCOLI et al., 2005). Within Hydrachnidia, new species for the Italian fauna were recorded, like Atractides fissus (Walter 1927) and Arrenurus conicus Piersig, 1894.

The deepest bottom of the same Alpine lakes, show limited animals usually very scarce and mainly represented by Chironomidae (Procladius and Tanytarsus), and Oligochaeta Naididae (Tubificinae, mainly Tubifex tubifex) (Mosello et al., 1993).

All of the mentioned groups are known to be acid tolerant (RADDUM \& FJellheim, 1984; Merilainen \& Hynynen, $1990)$ with the exception of Bivalvia which are more sensitive to acidification (RADDUM, 1980).

\section{Central eastern Alps}

On the eastern side of the Central Alps, more alkaline waters are found, with higher $\mathrm{pH}$ and alkalinity values, and a generally richer biodiversity (BOGGERO \& LENCIONI, 2006). In these lakes, noteworthy is the finding of: Lymnaea stagnalis (Linnaeus, 1758) (Mollusca), reaching its maximum altitude at $1500 \mathrm{~m}$ asl (DECET, 2007a), Niphargus strouhali cfr. alpinus Schellenberg, 1933, which is usually present at altitudes in the range of 2000-2200 $\mathrm{m}$ asl, and found here up to $2700 \mathrm{~m}$ asl, and Gammarus lacustris, common inhabitant of high altitudes (1900-2300 m asl) (LENCIONI, 2001). The latter species is a post-glacial relict with a fragmented and scattered distribution in the Central eastern Alps (from Carnic to Orobie). It appears again in the northern Central Apennines (from Liguria up to Abruzzo at altitudes higher than $1500 \mathrm{~m}$ as1), with a more uneven distribution than in the Alps (IANNILLI \& RUFFO, 2002). Like other boreo-alpine species of the Apennines, G. lacustris seems to have reached these areas from the north in a Quaternary glacial period, presumably during the Würm.

Chironomidae and molluscs are usually found, the former represented by Orthocladiinae (Cricotopus and Eukiefferiella) and Diamesinae (Diamesa spp.). Molluscs are mainly characterised by Pisidium casertanum, reaching here its highest altitude (2643 $\mathrm{m}$ asl), and by rare species like $P$. hibernicum Westerlund 1894 (NARDI \& CASTAGNOLO, 2009; NARDI, 2010a, 2010b).

A richer fauna is also found in lakes where water level fluctuations are low because of their greater depths, and, consequently present more stable shores, macrophytes (providing food, substrate and refuge), and a higher organic matter content (BICHTEler et al., 1998; FrANCESCHINI \& LENCIONI, 2002; LAZZARA et al., 2006).

The presence of an extended vegetation cover in the catchment related to a higher nitrogen atmospheric input, is also important for the presence and distribution of lake macroinvertebrates (FüREDER et al., 2006).

Since 2000, because of the increasing interest in mountain lakes and in Chironomidae, detailed analysis began and new or rare species were found in the southern side of the Central eastern Alps: Acamptocladius reissi Cranston and Saether 1982 (Ferrarese \& Lencioni, 2003), Cricotopus (Cricotopus) pirifer Hirvenoja, 1973, Psectrocladius oligosetus Wuelker, 1956 among Orthocladiinae, Paratanytarsus laccophilus (Edwards, 1929), Tanytarsus gibbosiceps Kieffer, 1922, T. sinuatus Goetghebuer, 1936, and $T$. mendax Kieffer, 1925 among Chironominae (FERRARESE, 2002). Among Oligochaetes, notable is the presence of Paranais litoralis Müller, 1784 and Pristinella idrensis (Stephenson 1932), typical of organic matter enriched environments in relation with cattle grazing (BOGGERO et al., 2012). In most of the cases, the presence of one or more inlets influences the lacustrine assemblage with strictly rheophilus species like: Zavrelimyia punctatissima (Goetghebuer 1934), Pseudodiamesa branickii (Nowicki, 1873), Eukiefferiella minor (Edwards 1929), Eusimulium aureum (Fries, 1824), Baetis alpinus (Pictet, 1843), and Crenobia alpina (FRANCESCHINI \& LENCIONI, 2002, BOGgERO \& LENCIONI, 2006).

\section{Western Alps}

In the oligotrophic waters of the Western Alps, the highly distributed groups are Coleoptera, Heteroptera, Diptera, Trichoptera, Ephemeroptera, Oligochaeta, and Platyhelmintes. Crenobia alpina (Dana, 1766) (Platyhelmintes) reaches here its maximum altitude $(2850 \mathrm{~m}$ asl TORTONESE \& ROSSI, 1954). Interesting is the finding of Gammarus lacustris in Lake La Maddalena (1996 m asl IANNILLI et al., 2004), near the Italian-French border, where amphipods had never been found before. This site represents also the only site in which the species is present in the Western Alps.

\section{Apennines}

Biodiversity in mountain lakes with high alkalinity values is less documented, but on the Apennines, where karstic lakes are present, macroinvertebrate assemblages are richer (taxa reaching in some occasion 40-80 units) and more varied than those present in acidic lakes ( $<25$ taxa). Since Apennines lakes are small and shallow, frequently considered ponds, their naturalistic value equalises their fragility towards human intervention, as they are unable to mitigate the effects of any stress (RUGGIERO et al., 2001). Thus, they are considered of exceptional value since they allow the survival of northern latitudinal species (widely distributed in the Alps and in central northern Europe), representing glacial relicts in Central Italy (Di GIORGIO \& ZUPPA, 1996). Noteworthy examples are the Trichoptera Sericostoma italicum Moretti, 1978 and Allogamus ausoniae Moretti, 1991 endemic in the Apennines, and the Coleoptera Agabus calchonatus (actually Ilybius chalconatus Panzer, 1797), sporadic almost everywhere (Di Giorgio \& ZuPPA, 1996). In particular, A. ausoniae 
finds here its southern limit of distribution. All these aspects justified the inclusion of most mountain areas of central Italy (mainly, Lazio and Abruzzo) into the protection of national parks, and of other minor protected areas.

Mainly because of livestock grazing, eutrophic lakes on the Apennines are not unusual at these altitudes. Their assemblages are generally represented by the same taxonomic groups found on the Alpine lakes, but are characterized by higher mean annual densities due to higher nutrient content that favour the development of phytoplankton and periphytic algae along the shores during the ice-free period. Chironomidae, in particular, are well represented by Natarsia sp., Paramerina divisa (Walker, 1856), Cricotopus (C.) tremulus (Linnaeus, 1758), Cricotopus (I.) trifasciatus (Meigen, 1810), Orthocladius consobrinus (Holmgren, 1869), Psectrocladius (Allop.) obvius (Walker, 1856), Dicrotendipes gr. tritomus (MARCHESONI \& MoretTi, 1954, BAZZANTI \& SEMINARA, 1987, Di Giorgio \& ZuPPA, 1996, RUGGIERO et al., 2001, 2004).

Finally, in the bottom area of reservoirs on the Apennines (BAZZANTI et al., 1988; SEMINARA \& BAZZANTI, 1988; SPITALE et al., 2015), studies conducted on the effects of hypo-limnetic draw-off and on the unnatural and variable water level drawdown showed that both impacts may favour the presence of active swimmers, instability- and pollutant-tolerant species like Dero digitata (Mueller, 1773) (Oligochaeta), Procladius choreus (Meigen, 1804) (Chironomidae) and Chaoborus flavicans (Meigen, 1830) (Chaoboridae), which avoid adverse environmental conditions by displacing actively following the water retreat. Ubiquitous sedentary mud-dwellers, like Tubifex tubifex (Müller, 1774), and Potamotrix hammoniensis (Michaelsen, 1901) (Oligochaeta), and Chironomus plumosus (Linnaeus, 1758) (Chironomidae), need more stable conditions to survive.

\section{CONCLUDING REMARKS}

In the 191 Italian mountain lakes considered in the paper, a total of 650 macroinvertebrate taxa were reported. Of these, only 354 were identified at the species level due to the presence of juveniles or poorly preserved specimens in the samples, or due to uncertainty of identification in presence of cryptic species and/or absence of a taxonomic expert. This emphasizes the huge taxonomic effort that still has to be undertaken to fully characterize these ecosystems. Nowadays, molecular approaches are becoming more and more important in providing methods for the faster identification of target species, or in monitoring these ecosystems. In particular, DNA barcoding, genomics and, to a lesser extent, proteomics of lacustrine macroinvertebrates seem to be promising as tools for taxonomic research and water quality assessment programs. Nonetheless, even if some DNA barcoding libraries already exist, these are still broadly incomplete, and not completely finalized to the national territory. Therefore, at present, morphological taxonomy cannot be totally replaced by the sole DNA analysis.

More generally, even if a scarce direct anthropic pressure is present, because most mountain lakes are distant from urban areas and difficult to access, these systems can receive pollutants from regional and long-range atmospheric transport, thus making them extremely sensitive to environmental changes damaging their beauty and their charms, and most of all, their food-web structures. Therefore:

- there is an urgent need of including mountain lakes within tailored monitoring programs, in view of the maintenance and the preservation of these small habitats as important non-perennial sources of biodiversity. Even if the continuous control of the ecological status of these systems is a time-consuming and expensive effort, the assessment of long-term trends is becoming pivotal in order to understand the effects of direct or indirect human impacts, thus ensuring the wealth of these unique ecosystems. In particular, they need to be included under the monitoring programs of the Water Framework Directive legislation, that at present takes into consideration only lakes with an area $>0.5 \mathrm{~km}^{2}$;

- at this stage, every educational publication, even the shortest one, illustrating this often neglected branch of the scientific knowledge, is crucial. Increase the public awareness and attention is the only way we have to promote the protection of these systems and their fauna, and to stimulate political and conservational measures;

- improving advanced techniques such as remote sensing (image acquisition performed through sensors) undertaken concurrently to the traditional monitoring approach, both chemical and biological (phytoplankton and macroinvertebrates), will represent the frontier to acquire synoptic data on habitat conditions, especially in hardly accessible areas such as remote mountains;

- at the European level, the INSPIRE Directive (INfrastructure of SPatial InfoRmation in Europe - 2007/2/EC) promotes the creation of services that allow the storing, the availability and the sharing of data among different institutions, with the aim of ensuring that the future environmental policies will be based on big, easily accessible and interoperable data, ensuring their effectiveness. This must constitute another chance for studying and, therefore, developing further conservation strategies for such unstable and uneven environments.

Biodiversity is our natural heritage. It needs to be preserved for our and future generations. Freshwater ecosystems at high altitude are under threat. They are becoming prominent examples of the current global scale magnitude of species extinction (1000 times higher than the natural background rate). They provide ecosystem services constituting the basis of the economy of the European States that share with Italy the presence of mountains within their borders. Limit the biodiversity loss and the declining ecosystem services is thus the prominent challenge we have to deal in the next future.

\section{ACKNOWLEDGEMENTS}

Special thanks are due to Prof. Stefano Fenoglio (Univ. Piemonte Orientale, Italy), for his invaluable help in the revision of the first draft of the paper, and for his ever-present support and encouragement. I'm also grateful to my husband (Gianfranco Varini) for his support in cataloguing lakes and in finding their morphological and geographical information. I am also in debt with Laura Puppieni (librarian of the CNR-ISE, Italy), without whose assistance this work would not have seen the light. Thanks are also due to three anonymous referees for their top quality review, and to all the numerous colleagues (too many to mention here) that provided papers and pdf copies otherwise untraceable. Finally, I would like to thank Drs Giambattista Nardi (freelance molluscs expert, Italy), Rosario Mosello, Aldo Marchetto, Laura Garzoli and Ester Eckert (CNR-ISE, Italy) for the information they sent, and for their suggestions and amendments of the English version of the manuscript.

\section{REFERENCES}

AAGAARD K., 1986 - The chironomid fauna of north Norwegian lakes, with a discussion on methods of community classification. - Holarctic Ecology, 9: 1-12.

Allan J.D., CASTILlo M.M., 2007 - Stream ecology: structure and function of running waters. Springer, Netherlands. 
Ansaloni I., Benassi A., Manzieri A.M., Ruocco M., SAla L., TINTORRI A., 2015 - Il Lago della Ninfa (Appennino modenese): comunità macrozoobentonica, fauna vertebrata e considerazioni ecologiche. - Atti della Società dei Naturalisti e Matematici di Modena, 146: 249-262.

ANSAloni I., Prevedelli D., Ruocco M., Simonini R., 2016 - Checklist of benthic macroinvertebrates of the Lago Pratignano (Northern Apennines, Italy): an extremely rich ecosystem. - Check List, 12(1): 1821. 8 pp.

BALDI E., 1941 - Ricerche idrobiologiche al Lago di Tovel. Memorie del Museo di Storia Naturale della Venezia tridentina, 6: $297 \mathrm{pp}$.

BARBAto G., 1984 - Indagine su 27 laghi delle Alpi e Prealpi bresciane. - Monografie di Natura Bresciana, 6: 122 pp.

BAZZANTI M., SEMINARA M., 1987 - Environmental stress in a regulated eutrophic lake indicated by the profundal macrobenthic community. - Bollettino di Zoologia, 54: 261-266.

Bazzanti M., Seminara M., Tamorri C., 1988 Macrobenthos profondo del Lago artificiale di Campotosto (Abruzzo, Italia Centrale). - Rivista di Idrobiologia, 27: 161-175.

Biancotti A., Boggero A., Brusa G., Manca M., Marchetto A. Movalli C., Morelli C., 2001 - Creste e zone umide. Ente Parco Nazionale ValGrande, Collana Studi 2. Press Grafica, Verbania, pp. 63.

Bichteler A., Lencioni V., Nespoli L., Tessari P., 1998 Limnology of a subalpine lake: Lake Tovel. - Zoobenthos. Report.

BLESIO P., 1985 - Appunti di idrobiologia animale. In: Berruti G., Biagi P., Blesio P., Crescini A., De Carli C., Rapuzzi F., Valetti O., (editors). Laghi alpini del bresciano, Editoriale Ramperto, Brescia: 104-106.

Boggero A., Nocentini A.M., 1994 - Macrozoobentos di un lago alpino d'alta quota (Lago Paione Superiore, Val Bognanco). - Atti X Congresso AIOL, 4-6 Novembre 1992, Alassio: 177-187.

BOGGERO A., 1995 - Analysis of the littoral macrobenthic community of Alpine lakes sensitive to acidification (Canton Ticino, Switzerland). - Final Report NATO. CNR, Senior Fellowship Programme 1994: pp. 28

Boggero A., Nocentini A.M., Nobili M., Gianatti M., 1996 - Ricerche sulla fauna macrobentonica litorale in laghi d'alta quota nel bacino imbrifero del Lago Maggiore. - Atti XVII Congresso Nazionale S.It.E., 11-14 Settembre 1996, Napoli: 83-86.

Boggero A., NobiLi M., 1998 - Macrobenthic community and chemical characteristics of four Alpine lakes in Canton Ticino. - Bollettino della Società Ticinese di Scienze Naturali, 86: 17-23.

Boggero A., Movalli C., 2001 - Vivere in quota. - Guida alla mostra: Ambienti estremi. Ente Parco Nazionale Val Grande, Collana Studi 1. Press Grafica, Verbania: pp. 63.

Boggero A., Marchetto A., Manca M., Mosello R., TARTARI G.A.,2005 - Studies on small mountain lakes in the Val Grande National Park (Central Alps, Italy). - Studi Trentini di Scienze Naturali, Acta Biologica, 82: 43-54.

Boggero A., Füreder L., Lencioni V., Simcic T., Thaler B., Ferrarese U., Lotter., EtTINGER R., 2006 - Littoral Chironomid communities of Alpine lakes in relation to environmental factors. In: Lami A., Boggero A., editors. Ecology of high altitude aquatic systems in the Alps. Hydrobiologia, 562: 145-165.

BogGero A., LENCIONI V., 2006 - Macroinvertebrates assemblages of high altitude lakes, inlets and outlets in the southern Alps. - Archiv für Hydrobiologie, 165: 37-61.

Boggero A. Rossaro B., Lencioni V., Bazzanti M., MASTRANTUONO L., SOLIMINI A., 2009-Macroinvertebrati di acque lacustri: stato attuale delle conoscenze e prospettive future. VIII Giornata mondiale dell'acqua "Acque interne in Italia: uomo e natura". - Atti dei Convegni Lincei, 250: 177-184.

Boggero A., Rogora M., Musazzi S., Lami A., 2012 Attività di campagna e di laboratorio 2012. WP 2 risorsa acqua: Caratteristiche di qualità e quantità. Share-Stelvio un parco-osservatorio per lo studio dei cambiamenti climatici in alta quota, pp. 18.

Boggero A., Rogora M., Musazzi S., Zaupa S., Lami A., Salerno F., Guzzella L., Gambelli S., Guyennon N., Viviano G., ThaKuri S., TARTARI G., 2013 - Un mondo d'acqua in alta quota. Le acque del Parco Nazionale dello Stelvio, un laboratorio a cielo aperto per lo studio dei cambiamenti climatici. - Ev-K2-CNR, pp. 90.

Boggero A., Garzoli L., VArINI G., 2017 - An historical and geographic data set on the distribution of macroinvertebrates in Italian mountain lakes. - Biogeographia - The Journal of Integrative Biogeography, 32: 77-87.

Boggero A., Zaupa S., Musazzi S., Rogora M., Dumnicka E., LAMI A., Submitted - Environmental factors as key drivers for mountain lakes biodiversity (Rhaetian Alps, Italy). - Hydrobiologia.

Boni C., Bresolin R., Casellato S.S., Lunelli F., 1983 - Le comunità zooplanctonica e zoobentonica del Lago di Tovel, espressioni della sua oligotrofia. - Studi Trentini di Scienze Naturali, 60: 25-53.

BOURCART F.E., 1906 - Les lacs alpins suisses, étude chimique et physique. - Thèse présentée à l'Université de Genève. Georg and Co. editeurs, Genève, 127 pp.

BRUNDIn L., 1956 - Zur Systematik der Orthocladiinae (Diptera Chironomidae). - Institute of Freshwater Research, Drottningholm. Report, 37: 5-185.

BuFFA P., 1902 - Sulle condizioni fisiche e biologiche di taluni laghi alpini del Trentino. - Atti della Società venetotrentina di Scienze Naturali, 3E:1-52.

Cantonati M., Guella G., Spitale D., Angeli N., Borsato A., Lencioni V., FILIPPI M.L., 2014 - The contribution of lake benthic algae to the sediment record in a carbonate mountain lake influenced by marked natural water-level fluctuations. - Freshwater Science, 33: 499-512.

CAPPelletti C., Ciutti F., Gramegna C., 2004 - Evoluzione del popolamento dei Tricotteri del Lago di Tovel. - Studi Trentini di Scienze Naturali, Acta Biologica, 81:379-382.

Casellato S., ZANFeI M., 1988 - Primo quadro limnologico generale del Lago di Lavarone (Trento, Italia). - Studi Trentini di Scienze Naturali, 64: 135-156.

Catalan J., Barbieri M.G., Bartumeus F., Bitusik P., Botev I., Brancelu A., Cogalniceanu D., Manca M., Marchetto A., Ognjanova-Rumenova N., Pla S., Rieradevall M., Sorvari S., Stefkova E., Stuchlik E., VENTURA, 2009 -Ecological thresholds in European alpine lakes. - Freshwater Biology, 54: 2494-2517.

Chambers P.A., Lacoul P., Murphy K.J., Thomaz S.M., 2008 - Global diversity of aquatic macrophytes in freshwater.-Hydrobiologia, 595: 9-26.

Cianficconi F., MoretTi G., 1992 - Catalogo dei Tricotteri delle Alpi occidentali. Considerazioni zoogeografiche.Biogeographia, 16: 257-295.

Dal Cortivo M., Decet F., Fossa I., Gatti E., 2009 Checklist degli Odonati della Provincia di Belluno (AlpiOrientali, Italia). - Lavori della Società Veneta di Scienze Naturali, 34: 5-19.

De MARCHI M., 1913a-Streblocerus serricaudatus nel Trentino. - Atti della Società italiana di Scienze Naturali, 51:207-219.

DE MARChI M., 1913b - Notizia sulla presenza di Moina rec- 
tirostris nel Trentino. -Rendiconti del Reale Istituto Lombardo di Scienze e Lettere, 46: 811-821.

DeCET F., Fossa I., 2001 - Catalogo dei molluschi terrestri e d'acqua dolce del Bellunese. - Bollettino del Museo Civico di Storia Naturale di Venezia, 51:39-117.

Decet F., 2007a - Capitolo IX. I Molluschi. In: Regione Veneto, ARPAV, editors. Studio della qualità delle acque dei piccoli laghi alpini: 235-243.

DECET F., 2007b - Capitolo X. Anfibi e Macroinvertebrati. In: Regione Veneto, ARPAV, editors. Studio della qualità delle acque dei piccoli laghi alpini: 245-250.

DECET F., 2007c - Capitolo VIII. Le Libellule (Odonati). In: Regione Veneto, ARPAV, editors. Studio della qualità delle acque dei piccoli laghi alpini: 225-233.

Di Giorgio M., Zuppa A.M., 1996 - Macrobenthos dei laghetti di quota del Gran Sasso e del tratto sorgentizio del torrente Nora. Appennino abruzzese, nota preliminare. In: Cicolani B., editor. Monitoraggio biologico del Gran Sasso. Consorzio di ricerca "Gran Sasso", Università degli Studi dell'Aquila, pp. 284-289.

Di Sabatino A., Boggero A., Cicolani B., Miccoli F.P., 2004 - Diversity, distribution and ecology of water mites (Acari: Hydrachnidia and Halacaridae) in high Alpine lakes (Central Alps, Italy). - Experimental and Applied Acarology, 34: 199-210.

DuMnICKA E., BogGero A., 2007. Freshwater Oligochaeta in two mountain ranges in Europe: the Tatra Mountains (Poland) and the Alps (Italy). - Archiv für Hydrobiologie, 168: 231-242.

DuMniCKA E., Boggero A., 2017 - Cernosvitoviella species (Oligochaeta, Enchytraeidae) from Alpine freshwaters. Research \& Reviews. Journal of Zoological Sciences, 5 : 25-34.

EU, 2000 - Directive 2000/60/EC of the European Parliament and of the Council of 23 October 2000 establishing a framework for community action in the field of water policy. - Official Journal of the European Communities, $72 \mathrm{pp}$.

EVANGELISTA M., 2009 - Contributo alla conoscenza dei molluschi del Parco Naturale del Monte Avic (Valle d'Aosta, Italia $N W$ ). - Revue Valdôtaine d'Histoire Naturelle, 63: 99-124.

FACCHINI R., BADINO G., 1998 - I macroinvertebrati come bioindicatori di biodiversità delle zone umide del Parco Naturale del Monte Avic. - Revue Valdôtaine d'Histoire Naturelle, 52: 49-77.

Fenoglio S., Bo T., Cucco M., Mercalli L., Malacarne G., 2010 - Effects of global climate change on freshwater biota: a review with special emphasis on the Italian situation. - Italian Journal of Zoology, 77: 374-383.

Ferrarese U., 2002 - Chironomidi (Diptera: Chironomidae) di alcuni torrenti, laghi e zone umide del Trentino, con segnalazione di specie nuove per l'Italia. - Studi Trentini di Scienze Naturali, Acta Biologica, 79: 203-211.

FERRARESE U., LENCIONI V., 2003 - Acamptocladius reissi Cranston and Saether, 1982 (Diptera Chironomidae): the first Italian records. - Lavori della Società Veneziana di Scienze Naturali, 28: 77-78.

FERRARI I., BELlAVERE C., 1976 - Ricerche ecologiche su zooplancton e macrozoobenton del Lago Santo Parmense. - Rivista di Idrobiologia, 151:3-45.

Filippi M.L., Heiri O., ARPENTI E., ANGeli N., BortolotTI M., LotTer A.F., VAN Der Borg K., 2005a - Evoluzione paleoambientale dal Tardoglaciale a oggi ricostruita attraverso lo studio dei sedimenti del Lago di Lavarone (Altopiano di Folgaria e Lavarone, Trentino). - Studi Trentini di Scienze Naturali, Acta Geologica, 82: 279-298.
FilipPi M.L., Heiri O., ArPenti E., Angeli N., Bortolotti M., LotTer A.F., VAN Der Borg K., 2005b - Studio paleolimnologico del Lago Nero di Cornisello (Parco Naturale Adamello-Brenta, Trentino). - Studi Trentini di Scienze Naturali, Acta Geologica, 82: 261-278.

Fuellheim A., Boggero A., Halvorsen G.A., Nocentin A.M., Rieradevall M., Raddum G.G., Schnell Ø.A., 2000 - Distribution of benthic invertebrates in relation to environmental factors. A study of European remote alpine lake ecosystems. - Verhandlungen des Internationalen Verein Limnologie, 27: 484-488.

FJellheim A., RAdDUM G.G., VANDVIK V., COGĂLniceAnU D., Boggero A., Brancelj A., Galas J., Sporka F., Vidinova Y., Bitusik P., Dumnicka E., GÂldean N., Kownacki A., Krno I., Preda E, Rîșnoveanu G., STUCHLIK E., 2009 - Diversity and distribution patterns of benthic invertebrates along alpine gradients. A study of remote European freshwater lakes. - Advances in Limnology, 62: 167-190.

Franceschini A., Lencioni V., 2002 - Lo zoobenthos (Capitolo 6). In: Cantonati M., Tolotti M., Lazzara M., editors. I laghi del Parco Adamello-Brenta. Ricerche limnologiche su laghi d'alta quota del settore siliceo del Parco. Documenti del Parco, 14: 245-266.

Füreder L., Ettinger R., Boggero A., Thaler B., Thies H., 2006 - Macroinvertebrate diversity in Alpine lakes: effects of altitude and catchment properties. In: Lami A., Boggero A., editors. Ecology of high altitude aquatic systems in the Alps. - Hydrobiologia, 562: 123-144.

GambetTA L., 1932 - Molluschi. In: Festa E., editor. Il Parco Nazionale del Gran Paradiso. Cecchini, Torino, 3: 139144.

Garibaldi L., Mosello R., Rossaro B., Setti F., 1987 Caratteristiche chimiche e biologiche di due laghi d'alta quota suscettibili ad acidificazione. In: Mosello R., De Margaritis B., editors. Deposizioni acide: un problema per Acque e Foreste. - Documenta dell' Istituto Italiano di Idrobiologia, 14: 165-180.

Gianotti F.S., Di Giovanni M.V., 1971 - Prime note biogeografiche sui laghi Pantaniello e Vivo (Appennino Abruzzese). - Società Italiana di Biogeografia, II: 575-581.

Grace J., BERNINGER F., NAGY L., 2002 - Impacts of climate change on the tree line. - Annals of Botany, 90: 537-544.

Guilizzoni P., Marchetto A., Lami A., CAmeron N.G., Appleby P.G., Rose N.L., Schnell Ø.A., Belis C.A., GIORGIS A., GuZzI L., 1996 - The environmental history of a mountain lake (Lago Paione Superiore, Central Alps, Italy) for the last c. 100 yrs: a multidisciplinary, palaeolimnological study. - Journal of Paleolimnology, 15:245-264.

HAUER F.R., RESH V.H., 2006 - Macroinvertebrates. In: Hauer F.R., Lamberti G.A., editors. Methods in stream ecology. Academic Press, San Diego, California, pp. 435463

HeIRI O., Filippi M.L., LotTer A.F., 2005 - Late glacial summer temperature in the Trentino area (Northern Italy) as reconstructed by fossil chironomid assemblages in Lago di Lavarone (1100 m a.s.l.). - Studi Trentini di Scienze Naturali, Acta Geologica, 82: 299-308.

IANNILli V., Ruffo S., 2002 - Apennine and Sardinian species of Gammarus, with the description of Gammarus elvirae n. sp. (Crustacea Amphipoda, Gammaridae). Bollettino dell'Accademia Gioenia di Scienze Naturali, 35: 519-532.

IANNILli V., De Matthaeis E., Vigna TAglianti A., 2004 Gammarus lacustris (Amphipoda, Gammaridae) nella fauna italiana. - Studi Trentini di Scienze Naturali, Acta Biologica, 81: 149-156. 
KALlENBORN R., 2006 - Persistent organic pollutants $(P O P S)$ as environmental risk factors in remote high-altitude ecosystems. - Ecotoxicology and environmental safety, 63: 100-107.

Kansanen P.H., Aho J., PaAsivirta L., 1984 - Testing the benthic lake type concept based on chironomid associations in some Finnish lakes using multivariate statistical methods. - Annales Zoologici Fennici, 21: 55-76.

Khamis K., Hannah D.M., Brown L.E., Tiberti R., MilneR A.M., 2014 - The use of invertebrates as indicators of environmental change in alpine rivers and lakes. - Science of the Total Environment, 493: 1242-1254.

KÖRNER C., 1998 - A re-assessment of high elevation treeline positions and their explanation. - Oecologia, 115: 445-459.

LAMi A., Rogora M., Boggero A., MusazZI S., TornimbenI O., 2011 - WP 2 Idrosfera. Campagna estiva 2011 per la caratterizzazione delle acque interne del Parco dello Stelvio, pp. 24

LARGAIOLLI V., 1907 - Ricerche biolimnologiche sui laghi trentini. 1. Il Lago di Tovel. - Rivista Mensile di Pesca, (1-23): 1-6.

LAZZARA M., LENCIONI V., MAIOLINI B., 2006 - Imacroinvertebrati (Capitolo 6). In: Cantonati M., Lazzara M., editors. I laghi di alta montagna del bacino del Fiume Avisio (Trentino orientale). - Monografie del Museo tridentino di Scienze Naturali, 3: 185-207.

LENCIONI V., 2001 - Lo zoobenthos. In: Lencioni V., Maiolini B., editors. L'ecologia di un ecosistema acquatico alpino (Val de la Mare, Parco Nazionale dello Stelvio). - Natura Alpina, 54: 59-68.

LENCIONI V., LAZZARA M., 2004 - I chironomidi subfossili (Diptera, Chironomidae) del Lago di Tovel (Trentino, Alpi centro-orientali): uno sguardo agli ultimi 400 anni. - Studi Trentini di Scienze Naturali, Acta Biologica, 81: 155-165.

LENZ F., 1925 - Chironomiden und Seetypenlehre. - Die Naturwissenschaften, 13: 5-10.

LUNDBECK J., 1936 - Untersuchungen über die Bodenbesiedlung der Alpenrandseen. -Archiv für Hydrobiologie, 10: 207-358.

Marchesoni V., Moretti G., 1954 - Appunti idrobiologici sul Lago di Pilato (q. m 1940) nei Monti Sibillini. Bollettino della Società Eustachiana, Anno XLVII, III: 131-144.

Marchetto A., Boggero A., Manca M., 2001 - Aree di cresta e zone umide: risultati delle ricerche. Aspetti ecologici delle piccole zone umide e delle sorgenti di quota. Ente Parco Nazionale ValGrande. Griggi, Baveno: 33-62.

Marchetto A., Mosello R., Rogora M., Manca M., Boggero A., Morabito G., Musazzi S., Tartari G.A., Nocentini A.M., Pugnetti A., Bettinetti R., Panzani P., Armiraglio M., Cammarano P., Lami A., 2004 - The chemical and biological response of two remote mountain lakes in the Southern Central Alps (Italy) to twenty years of changing physical and chemical climate. - Journal of Limnology, 63: 77-89.

Marchetto A., Rogora M., Boggero A., Musazzi S., Lami A., Lotter A.F., Tolotti M., Thies H., Psenner R., MASSAFERro J., BARBIERI A., 2009 - Response of alpine lakes to major environmental gradients, as detected through planktonic, benthic and sedimentary assemblages. - Advances in Limnolology, 62: 419-440.

Marcuzzi G., 1956 - Fauna delle Dolomiti. - Memorie dell'Istituto Veneto di Scienze, Lettere ed Arti, XXXI: 595 pp.

MARCUZZI G., 1961 - Supplemento alla fauna delle Dolomiti. - Memorie dell'Istituto Veneto di Scienze, Lettere ed Arti, XXXII: $131 \mathrm{pp.}$
MARCuZzi G., 1988 - La fauna delle Alpi. Manfrini Editori, Trento: $688 \mathrm{pp}$.

Marziali L., Lencioni V., Boggero A., Rossaro B., 2005 Distribuzione di Ditteri Chironomidi in laghi alpini e prealpini. Atti XXXV Congresso Società Italiana Biogeografia, Rabbi (TN) 6-9 settembre 2004. Biogeographia, XXVI: 431-445.

Mascagni A., Terzani F., 1983 - Raccolte di Odonati in Trentino-Alto Adige (Insecta: Odonata). - Studi Trentini di Scienze Naturali, Acta Biologica, 60: 55-65.

MASTRANTUONO L., 1987 - Invertebrate community in the littoral regulated area of a hydroelectric lake-reservoir (Lake Campotosto, Central Italy). - Rivista di Idrobiologia, 26: 17-32.

MERILAINEN J.J., HYNYNEN J., 1990 - Benthic invertebrates in relation to acidity in Finnish forest lakes. In: Kauppi P., Anttila P., Kenttamies K., editors. Acidification in Finland. Springer Verlag, Berlin Heidelberg, pp. 1029-1049.

Miccoli F.P., Cicolani B., Giustini M., Vignini P., Di SABAtino A., 2005 - Nuovi dati sulla distribuzione ed ecologia degli Acari acquatici (Acari: Hydrachnidia e Halacaridae) in Piemonte, con una checklist aggiornata delle specie. - Studi Trentini di Scienze Naturali, Acta Biologica, 82: 29-41.

Mietto S., Rossaro B., Lencioni V., 2000 - The Chironomid taxa of the Italian Lakes: a review. In: Hoffrichter O., editor. Proceedings of the Late 20th Century Research on Chironomidae: an anthology from the 13th International Symposium on Chironomidae. Shaker Verlag, Aachen, pp. 549-564.

Millet L., Vannière B., Magny M., De Beaulieu J.L., Disnar J-R., Laggoun-Défarge F., Verneaux V., Walter-Simonnet A-V., Ortu E., Bossuet G., 2007 Response of littoral chironomid community and organic matter to late glacial lake level and environmental changes at Lago dell'Accesa (Tuscany, Italy). - Journal of Paleolimnology, 38: 525-539.

Monti R., 1936 - Il Lago di Valparola. Stamperia Moderna, Roma, pp. 16.

Morabito G., Boggero A., Rogora A., Tartari G.A., Tornimbeni O., Mosello O., Bozelli R.L., Manca M., 2007-2008 - Limnologia d'alta quota in Val d'Aosta: il Lago Combal. - Revue Valdôtaine d'Histoire Naturelle, 6162:307-322.

MoretTi G., 1942 - Partecipazione dei tricotteri alle biocenosi costiere del L. di Tovel. - Memorie dell'Istituto italiano di Idrobiologia, 50: 295-306.

Moretti G.P., Corallini Sorcetti C., 1991 - Mise à jour des populations Trichopterologiques du Lac de Tovel. In: Tomaszewski C., editor. Proceedings VI International Symposium on Trichoptera. Adam Mickiewicz Publication, Poznan, pp. 39-44.

Mosello R., Lami A., Guilizzoni P., Manca M., Nocentini A.M., Pugnetti A., Boggero A., Marchetto A., TARtari G.A., BettinetTi R., Bonardi M., CAmmarano P., 1993 Limnological studies on two acid sensitive lakes in the Central Alps (lakes Paione Superiore and Paione Inferiore, Italy). - Memorie dell'Istituto italiano di Idrobiologia, 51: 127-146.

NARDI G., 2005 - Le “vongole” dei laghi alpini. - L'Aviolo (annuario della sezione di Edolo del Club Alpino Italiano), 25: 124-127.

Nardi G., Castagnolo L., 2009 - Il genere Pisidium Lamarck 1818 (Mollusca, Bivalvia, Sphaeriidae) nei laghi alpini della provincia di Brescia. Primo contributo: il bacino idrografico del Fiume Oglio. - Natura Bresciana, Annali del Museo Civico di Scienze Naturali, 36: 5-57. 
NARDi G., 2010a - I Bivalvi dei laghi alpini camuni. In: Comensoli D., editor. Laghi alpini di Vallecamonica: immagini, ambiente, itinerari. Moma Editrice, Bergamo, pp. 218-221.

NARDI G. 2010b - Contributo alla conoscenza della fauna dei laghi alpini bresciani. - Adamello (periodico della sezione di Brescia del Club Alpino Italiano), 108: 22-26.

NARDI G., 2014 - Il genere Pisidium Lamarck, 1818 (Bivalvia, Sphaeriidae) nei laghi alpini della provincia di Brescia. Secondo contributo: il bacino idrografico del fiume Caffaro. - Bollettino Malacologico, 50: 33-53.

NARDINI A., SANSONI G., editors. 2006 - La riqualificazione fluviale in Italia. Linee guida, strumenti ed esperienze per gestire i corsi d'acqua e il territorio. Mazzanti, Mestre, 832 pp.

NAUMANn E., 1921 - Einige Grundlinien der regionalen Limnologie. - Lunds Universitets Årsskrift, 17: 1-21.

NIVA, 1987 - International cooperative programme for assessment and monitoring of acidification of rivers and lakes: programme manual. Programme Centre, NIVA, pp. 23.

NIVA, 1995 - International cooperative programme for assessment and monitoring of acidification of rivers and lakes. Preliminary: programme manual. Programme Centre, NIVA, pp. 34.

NIVA, 2010 -International cooperative programme for assessment and monitoring effects of air pollution on rivers and lakes. ICP Waters programme manual. Programme Centre, NIVA Report 105/2010, pp. 91.

NÖssing T.B., WinkLer Werth F., 2010 - Le libellule nei parchi naturali Monte Corno e Vedrette di Ries-Aurina. Provincia Autonoma di Bolzano-Alto Adige, pp. 31.

Novelli M., Meregalli M., Della Beffa G., 1997 Dytiscidae ed Helophoridae (Insecta, Coleoptera) del Parco Naturale del Mont Avic (Valle d'Aosta, Italia). Revue Valdôtaine d'Histoire Naturelle, 51:39-58.

Osella G., Pannunzio G., 2013 - Macrobenthos dei laghetti del Gran Sasso d'Italia. - Quaderni del Museo di Storia Naturale di Ferrara, 1: 57-67.

Paganelli A., 1992 - Lake Tovel (Trentino): limnological and hydrobiological aspects. - Memorie dell'Istituto italiano di Idrobiologia, 50: 225-257.

Parisi V., Valle A., Dematteis E., Magnetti P., Michelangeli M., Paoletti Di ChiaraA., Romagnoli Joppi F., Smedile E., Tibaldi E., Zullini A., 1968 Appunti per lo studio della fauna non vertebrata del Parco Nazionale dello Stelvio. - Istituto Lombardo (Rendiconti Scientifici) B, 102: 175-193.

PARKer B.R., Vinebrooke R.D., Schindler D.W., 2008 Recent climate extremes alter alpine lake ecosystems. Proceedings of the National Academy of Sciences, 105: 12927-12931.

Pero P., 1893 - I laghi alpini valtellinesi. Parte prima. Valle dell'Adda. Puntata prima. Nuova Notarisia, serie IV, 46 pp.

Pesta O., 1912 - Hochgebirgsseen in Tirol und Ihre Fauna. I. - Beitrag. Verhandlungen der Zoologisch-Botanischen Gesellschaft in Wien, 62: 158-171.

PSENNER R., 2002 -Alpine waters in the interplay of global change: complex links - simple effects. In: Steininger K.W., Weck-Hannemann H., editors. Global environmental change in alpine region: new horizons in environmental economics. Edward Eldgar, Cheltenham, UK, 271 pp.

RADDUM G.G., 1980 - Comparison of benthic invertebrates in lakes with different acidity. In: Drablos D., Tollan A., editors. Ecological impact of acid precipitation. SNSF Project, Oslo Norway, pp. 330-331.

RADDUM G.G., FJELLHEIM A., 1984 - Acidification and early warning organisms in freshwater in western Norway. Verhandlungen der Internationalen Vereinigung für Theoretische und Angewandte Limnologie, 22: 1973 1980.

Rogora M., Boggero A., Marchetto A., Mosello R., TARTARI G., ZAUPA S., 2014 - Laghi alpini: un mondo che cambia.-Nimbus, 72: 11-16.

Rossaro B., Boggero A., Lencioni V., Marziali L., 2010 Benthic macroinvertebrates as indicator in lakes. In: Bottarin R., Schirpke U., Tappeiner U., editors. Analisi spazio-temporali: dinamiche e processo a confronto. Atti XIX Congresso della Società Italiana di Ecologia, Dalle vette alpine alle profondità marine, $15-18$ settembre 2009 , Bolzano 2: 95-102.

Rossaro B., Boggero A., Buzzi F., Agostinelli C., Nastasi F., 2012 -Description of the larva of Protanypus sp. A (Diptera, Chironomidae) from the Italian Alps. - Journal of Entomological and Acarological Research, 44 (e6): 28-31.

Ruffo S., 1951 - Sulla presenza di Gammarus (Rivulogammarus) lacustris G.O. Sars nell'Appennino Ligure e nuovi reperti della specie per laghi alpini. Doriana, 1: 1-8.

Ruggiero A., Solimini A.G., Mutschlechner A., Anello M., CARChini G., 2001 - Aspetti limnologici del Lago Racollo (1568 m s.l.m.), Campo Imperatore (AQ). - Studi Trentini di Scienze Naturali, Acta Biologica, 78: 173-180.

Ruggiero A., Solimini A.G., Carchini G., 2004 Limnological aspects of an Apennine shallow lake. Annales de Limnologie, International Journal of Limnology, 40: 89-99.

Salerno F., Gambelli S., Viviano G., Thakuri S., Guyennon N., D’Agata C., Diolaiuti G., Smiraglia C., Stefani F., Bocchiola D., TARTARI G., 2014 - High alpine ponds shift upwards as average temperatures increase: a case study of the Ortles-Cevedale mountain group (Southern Alps, Italy) over the last 50 years. - Global and Planetary Change, 120: 81-91.

SEMINARA M., BAZZANTI M., 1988 - Trophic level assessment of profundal sediments of the artificial lake Campotosto (central Italy), using midge larval community (Diptera: Chironomidae). - Hydrobiological Bullettin, 22: 183-193.

Sommani E., 1952 - Limnologia dei laghi artificiali. II. Il lago di Campotosto - Bollettino di Pesca, Piscicoltura e Idrobiologia, 7: 93-111.

SOMMARUGA R., 2001 - The role of solar UV radiation in the ecology of alpine lakes. - Journal of Photochemistry and Photobiology B: Biology, 62: 35-42.

Spitale D., Angeli N., Lencioni V., Tolotti M., Cantonati M., 2015 - Comparison between natural and impacted Alpine lakes six years after hydropower exploitation has ceased. - Biologia, 70/12: 1597-1605.

Tartari G., Buraschi E., Legnani E., Previtali L., Pagnotta R., Marchetto A., 2006 - Tipizzazione dei laghi italiani secondo il Sistema B della Direttiva 2000/60/CE. Documento presentato al Ministero dell'Ambiente e della Tutela del Territorio e del Mare. CNR, pp. 20.

TERZANi F., 1977 - Una popolazione di Aeschna juncea L., 1758 al laghetto del Passo di Lavazè (Trento). - Rivista Entomologica, 2:18-19.

Thienemann A., 1954 - Chironomus Leben Verbreitung und wirtschaftliche Bedeutung der Chironomiden. - Die Binnengewässer, 20: $834 \mathrm{pp}$.

Tierno de Figueroa J.M., LóPEZ-Rodríguez M.J., FenOgLiO S., SÁNCHEZ-Castillo P., FochetTi R., 2012 - Freshwater biodiversity in the rivers of the Mediterranean Basin. Hydrobiologia, 719: 137-186. 
Tolotti M., Manca M., Angeli N., Morabito G., Thaler B., RotT E., StUChlik E., 2006 - Phytoplankton and zooplankton associations in a set of Alpine high altitude lakes: geographic distribution and ecology. - Hydrobiologia, 562: 99-122.

Tonolli V.,1949 - Gli alti laghi della Val Bognanco. Parte II. - Memorie dell'Istituto italiano di Idrobiologia, 5: 41-93.

TORTONESE E., Rossi L., 1954 - Contributo allo studio biologico del Parco Nazionale del Gran Paradiso (Alpi Piemontesi). Gran Piano di Noasca e dintorni. - Atti della Società Italiana di Scienze Naturali, 93: 437-488.

Wiederholm T., 1981 - Associations of lake-living Chironomidae. A cluster analysis of Brundin's and recent data from Swedish lakes. - Swiss Journal of Hydrology, 43:140-141.

WhitAKer J.O., AMLANER C. JR., (editors), 2012 - Habitats and Ecological Communities of Indiana: Presettlement to Present. Indiana University Press, 492 pp.

Zschoкке F., 1894 - Die Tierwelt der Jurasee. - Revue Suisse de Zoologie, 2: 349-376.
SUPPLEMENTARY MATERIAL TABLE 1 WITH LEGEND

(http://www.redia.it/images/stories/pdf2018/Boggero_ review per\%20Redia 2018 Tab1.xlsx)

Table 1 - List of the Italian mountain lakes divided per mountain range and administrative regions. Geographic (latitude, longitude, altitude) and morphometric (max depth) information is also presented for each lake. The table also provides the list of published papers, and the type of frequency data format found in each paper. $\mathrm{P}=$ presence of a taxon; $\mathrm{A}=$ data expressed as total number of individuals; $\mathrm{D}=$ data expressed as density (ind $\mathrm{m}^{-2}$ ); $\mathrm{R}=$ data expressed as relative abundances $(\%)$. The last column reports the number of lakes considered by each paper. Papers not reporting any species list were not considered in this table. 
46 - Blank Page 